Published in: International Journal of Manpower, 2021, Article

\title{
Life Satisfaction of Employees, Labour Market Tightness and Matching
}

\section{Efficiency}




\section{Life Satisfaction of Employees, Labour Market Tightness and Matching Efficiency}

\section{Abstract}

Di Tella et al. (2001) show that temporary fluctuations in life satisfaction (LS) are correlated with macroeconomic circumstances such as gross domestic product, unemployment, and inflation. In this paper, we bring attention to labour market measures from search and matching models (Pissarides 2000). Our analysis follows the two-stage estimation strategy used in Di Tella et al. (2001) to explore sectoral unemployment levels, labour market tightness, and matching efficiency as LS determinants. In the first stage, we use a large sample of individual data collected from a continuous web survey during the 2007-2014 period in the Netherlands to obtain regression-adjusted measures of LS by quarter and economic sector. In the second-stage, we regress LS measures against the unemployment level, labour market tightness, and matching efficiency. Our results are threefold. First, the negative link between unemployment and an employee's LS is confirmed at the sectoral level. Second, labour market tightness, measured as the number of vacancies per job-seeker rather than the number of vacancies per unemployed, is shown to be relevant to the LS of workers. Third, labour market matching efficiency affects the LS of workers differently when they are less satisfied with their job and in temporary employment. Our results give support to government interventions aimed at activating demand for labour, improving the matching of job-seekers to vacant jobs, and reducing information frictions by supporting match-making technologies.

Masaryk University

Faculty of Economics and Administration

Authors:

Pablo de Pedraza / AIAS, University of Amsterdam \& JRC European Commission

Martin Guzi (ORCID: 0000-0001-9936-3175) / Masaryk University, CELSI \& IZA

Kea Tijdens / AIAS, University of Amsterdam

Contact: pablo.depedraza@ec.europa.eu

Creation date: $2020-05$

Revision date: 2023-01

Keywords: life satisfaction, matching efficiency, tightness, unemployment

JEL classification: E24, J21

Citation:

de Pedraza, P., Guzi, M., Tijdens, K. (2020). Life Satisfaction of Employees, Labour Market Tightness and Matching Efficiency. MUNI ECON Working Paper n. 2020-02. Brno: Masaryk University. https://doi.org/10.5817/WP_MUNI_ECON_2020-02 


\title{
Life Satisfaction of Employees, Labour Market Tightness and Matching Efficiency \\ Pablo de Pedraza ${ }^{1}$
}

AIAS, University of Amsterdam and JRC European Commission

\section{Martin Guzi}

Masaryk University, CELSI and IZA

Kea Tijdens

AIAS, University of Amsterdam

\begin{abstract}
Di Tella et al. (2001) show that temporary fluctuations in life satisfaction (LS) are correlated with macroeconomic circumstances such as gross domestic product, unemployment, and inflation. In this paper, we bring attention to labour market measures from search and matching models (Pissarides 2000). Our analysis follows the two-stage estimation strategy used in Di Tella et al. (2001) to explore sectoral unemployment levels, labour market tightness, and matching efficiency as LS determinants. In the first stage, we use a large sample of individual data collected from a continuous web survey during the 20072014 period in the Netherlands to obtain regression-adjusted measures of LS by quarter and economic sector. In the second-stage, we regress LS measures against the unemployment level, labour market tightness, and matching efficiency. Our results are threefold. First, the negative link between unemployment and an employee's LS is confirmed at the sectoral level. Second, labour market tightness, measured as the number of vacancies per job-seeker rather than the number of vacancies per unemployed, is shown to be relevant to the LS of workers. Third, labour market matching efficiency affects the LS of workers differently when they are less satisfied with their job and in temporary employment. Our results give support to government interventions aimed at activating demand for labour, improving the matching of job-seekers to vacant jobs, and reducing information frictions by supporting match-making technologies.
\end{abstract}

JEL codes: E24, J21

Keywords: life satisfaction; matching efficiency; tightness; unemployment.

\footnotetext{
${ }^{1}$ Corresponding author: Pablo de Pedraza, European Commission, DG Joint Research Centre, Directorate I Competences, Unit I.1 - Modelling, Indicators and Impact Evaluation, Competence Centre on Composite Indicators and Scoreboards (COIN), E-mail: pablo.depedraza@ec.europa.eu
} 


\section{Introduction}

This paper aims to explore whether matching efficiency and labour market tightness influence the life satisfaction of employed workers (Pissarides 2000; Petrongolo and Pissarides 2001; Kahneman and Sugden 2005; Biswas-Diener, Kashdan and King 2009; Synard and Gazzola 2017). As far as we know, no evidence of this relationship has been documented before. Life satisfaction (LS) is moderately stable over time and related to personality and life contextual circumstances (Lucas et al. 2003; Lucas 2007; Lucas and Donnellan 2007). Di Tella et al. (2001; 2003) show that temporary fluctuations in LS are correlated with macroeconomic circumstances measured by gross domestic product, unemployment, and inflation. These results have been confirmed repeatedly (Dluhosch and Horgos 2013; Blanchflower et al. 2014; Akay et al. 2017). The event of job loss is negatively related to the experience of well-being (e.g. Synard and Gazzola 2017; Paul and Moser 2009; Mckee-Ryan et al. 2005). In addition, people are sensitive to unemployment even when they themselves are not unemployed (Leuchinger et al. 2010). The fact that employed people care about unemployment is explained by the fear of losing one's job as well as by the general negative consequences of unemployment on the whole society. Specifically, employees with temporary contracts and employees in industries with relatively high turnover, such as retail, are likely to be concerned due to perceived higher job insecurity (Theodossio and Vasileiou 2007; Origo and Pagani 2009; Muñoz de Bustillo and Pedraza 2010; Böckerman et al. 2011). Job uncertainty and the fear of losing one's job have a strong negative influence on the LS of workers (Guzi and Pedraza 2015). Employability and subjective job prospects matter to LS, showing that individuals who perceive better employment prospects in the event of a job loss report higher LS (Silla et al. 2009; Dickerson and Green 2012).

In this paper, we hypothesise that the LS of employed individuals is correlated with macroeconomic variables reflecting the context and characteristics of the search and matching processes between labour supply and demand. Rising unemployment levels will increase workers' feelings of job insecurity, make them aware of their unemployment risks and re-employment probabilities, and induce them to start searching for another job while still employed. We hypothesise that LS is affected by factors beyond unemployment levels, namely by the contextual circumstances of the search and matching processes, defined as the number of vacancies per job-seeker and the matching efficiency. We build on research showing that workers operating in tight markets, and thus with more vacancies per job-seeker, are likely to express higher LS as their re-employment probabilities are higher because favourable contextual labour market circumstances will positively contribute to their self-esteem, feeling valued and being in control (Lucas and Donnellan 2007; Silla et al. 2009; Dickerson and Green 2012). The link is expected to be different for workers dissatisfied with their current job or afraid of losing it, such as those in temporary employment, because they are more likely to look for a job while employed (Gerritsen and Høj 2013). We also hypothesise that in tight markets the LS of employed individuals who do not actively search for a job is positively affected because a higher number of vacancies per job-seeker may tilt the 
bargaining power with their employers in their favour. Regarding matching efficiency, labour markets with lower friction (i.e. higher matching efficiency) are expected to lead to higher LS. The paper focuses on employed workers, among other reasons, because it allows accounting for working conditions in the LS measures. The paper does not explore the extrapolation of conclusions to the whole labour force.

The analysis reported in this paper relies on the two-stage estimation strategy used by Di Tella et al. (2001). In the first stage, we employ a large sample of individual data collected between 2007 and 2014 from a continuous web survey in the Netherlands to obtain two regression-adjusted measures of wellbeing by quarter and economic sector. The first measure takes into account personal and demographic characteristics, while the second measure also accounts for work-specific characteristics, such as type of contract and job satisfaction. These residual sector- and quarter-specific well-being measures become the dependent variables in the second stage. The independent variables in the second stage are aggregated labour market characteristics defined by quarter and sector, namely unemployment, market tightness, and matching efficiency.

Our findings are threefold. First, we confirm that the unemployment level is negatively related to LS, which corroborates the findings of the previous literature. While Di Tella et al. (2001) show the importance of the unemployment level at the national level, our results corroborate the importance of unemployment at the sectoral level. Second, labour market tightness, measured as the number of vacancies per job-seeker rather than the number of vacancies per unemployed, is shown to be relevant to the LS of workers. An important nuance is that employed individuals are concerned about labour market tightness that takes into account the role of employed job seekers rather than a measure that considers only the unemployed. This result corroborates findings from recent search and matching literature reporting evidence of the employed actively searching for jobs (Veracierto 2011; Sedláček 2016; Hall and Schulhofer-Wohl 2015; Van Ours 2015). Our results are consistent with findings that indicate employed individuals are concerned about job competition with other employed individuals rather than with the unemployed (Diamond 2011; Diamond and Sahin 2015; Abraham 2015; Pedraza et al. 2018). Third, labour market matching efficiency affects the LS of workers differently when we account for job satisfaction and temporary employment. In the remainder of this paper, we introduce the estimation strategy, describe the data sources and results, and then present our conclusions.

\section{Estimation strategy}

We adapt the two-stage approach proposed by Di Tella et al. (2001) to estimate the effect of sectoral unemployment, labour market tightness, and matching efficiency on the LS of employed workers. In the first stage, we use two individual life satisfaction regressions to obtain two life satisfaction residuals that we aggregate by sector and quarter and use as dependent variables in the second stage. We obtain the first LS measures by regressing the self-reported level of life satisfaction $L S_{i s t}$ by individual $i$ employed 
in sector $s$ in quarter $t$ on the set of personal and demographic characteristics $P_{i s t}$, which include gender, marital status, education, age, age squared, gross hourly wage, and a dummy variable indicating the residence in a rural area (equation 1). The second LS measure is obtained by estimating the same regression model augmented with work-related characteristics $W_{i s t}$, such as type of contract and satisfaction with a job (equation 2). Both models include sector and time fixed effects, $\mu_{s}$ and $\tau_{t}$, that help to remove the effect of unobserved differences pertinent to sectors that affect LS but do not change substantially during the period observed.

$$
\begin{aligned}
& L S_{i s t}=\beta P_{i s t}+\mu_{s}+\tau_{t}+\varepsilon_{i s t} \\
& L S_{i s t}=\beta P_{i s t}+\gamma W_{i s t}+\mu_{s}+\tau_{t}+\varepsilon_{i s t}
\end{aligned}
$$

The mean residual LS measures are then estimated for each sector $s$ in quarter $t$. From (1) we obtain a LS measure adjusted for individual personal characteristics $\left(\overline{L S P}_{s t}\right)$ and from (2) a LS measure adjusted for individual personal and working characteristics $\left(\overline{L S P W}_{s t}\right)$. These sector-by-quarter unexplained LS components then become dependent variables in the second-stage estimations (equations 5 and 6). We use two LS residual measures because the concerns and circumstances of workers satisfied with their job and with a permanent contract should be different from workers dissatisfied with their job and in temporary employment (Leuchinger et al. 2010; Bjørnskov 2014; Böckerman et al. 2011; Theodossio and Vasileiou 2007; Origo and Pagani 2009; Muñoz de Bustillo and Pedraza 2010).

Independent variables in the second-stage are calculated following recent findings from search and matching literature (e.g. Jolivet 2009; Veracierto 2011; Sedláček 2016; Barnichon and Figura 2015; Pedraza et al. 2018) and include unemployment, labour market tightness and labour market matching efficiency. The conventional measure of labour market tightness is expressed as a ratio of vacancies per unemployed or $\theta=V / U$ and captures the market power of workers. Higher values improve the prospects of job-seekers and hence should also improve their LS. Recent empirical literature on job search and matching shows that employed workers are active job-seekers (Gerritsen and Hoj 2013; Kahn 2012; Pedraza et al. 2018) and that during loose labour market periods employers respond by hiring employed rather than unemployed job applicants (Van Belle et al. 2018). Employed workers actively looking for a job compete with other employed workers rather than with the pool of unemployed (Diamond 2011; Diamond and Sahin 2015). Following this literature, we propose an alternative measure of labour market tightness that additionally accounts for employed job-seekers, expressed as a ratio of vacancies per number of job-seekers, or $\theta^{\prime}=V / J S$. The group of job-seekers includes the unemployed, who by definition are actively looking for a job, and employed workers actively looking for a job. Since 
information about employed job-seekers is not readily available ${ }^{2}$, we take the number of workers with tenure below twelve months as a good proxy of employed job-seekers in the Dutch labour market, as proposed by Pedraza et al. (2018). This is consistent with findings indicating that differences in job search attitudes among the employed are primarily defined by job tenure spells (Gerritsen and Hoj 2013; Kahn 2012).

Finally, matching efficiency is obtained by calculating the labour market matching function. Vacancies, posted by firms looking for workers, and workers looking for jobs meet in the labour market. The matching function is widely used in labour economics and macro-economic modelling to capture the labour market matching process and its frictions. The standard estimation of the matching function (3) is based on the log-linear model with a Cobb Douglas functional form (Pissarides 2000; Petrongolo and Pissarides 2001) as follows:

$$
\log \left(H_{s, t}\right)=\log \left(\lambda_{s, t}\right)+\beta_{1} \log \left(U_{s, t-1}\right)+\beta_{2} \log \left(V_{s, t-1}\right)+\omega_{t}
$$

where the number of hires $\left(H_{s, t}\right)$ in sector $s$ in period $t$ is explained by the stock of unemployed $\left(U_{s, t-1}\right)$ and the stock of vacancies $\left(V_{s, t-1}\right)$ in that sector in period $t$ - 1 . From (3) we could obtain a measure of $\lambda_{s, t}$, the efficiency of the matching process that allocates unemployed workers to vacancies in sector $s$ in period $t$. The matching process is more efficient ( $\lambda$ is higher) when geographical location, skills and other characteristics of workers match those demanded by firms. The standard matching function assumes that the stock of the unemployed and vacancies are, respectively, accurate measures of labour demand and supply (Pissarides 2000; Petrongolo and Pissarides 2001). Similarly to labour market tightness, the literature shows that omitting employed job-seekers produces an omitted variable bias when estimating matching efficiency (Jolivet 2009; Veracierto 2011; Sedláček 2016; Pizzinelli and Speigner 2017). For example, omitting employed job-seekers from the matching function estimation may overestimate matching efficiency and lead to an erroneous conclusion about the presence of constant returns to scale in the matching process and how hires generate outflow from unemployment (Barnichon and Figura 2015; Pedraza et al. 2018). A suggested estimation of the matching efficiency accounts for heterogeneities in both sides of the labour market, such as different types of job-seekers and vacancies (Jolivet 2009). By following the approach of Pedraza et al. (2018) and Jolivet (2009), we estimate the alternative measure of matching efficiency $\lambda_{s, t}^{\prime}$ from a matching function that uses labour supply $\left(S_{s, t}\right)$ and labour demand $\left(D_{s, t}\right)$ measures defined as follows:

\footnotetext{
${ }^{2}$ LFS includes a question about seeking a job (SEEKWORK cf. LFS user's guide). Data obtained from aggregating that variable by sector and by quarter are "not publishable" and are statistically unreliable according to EU-LFS publishing guidelines.
} 


$$
\begin{aligned}
& S_{s, t}=U_{s, t-1}+\text { new } U_{s, t}+\text { Short term } E_{s, t}+I_{s, t} \\
& D_{s, t}=V_{s, t-1}+\text { new } V_{s, t}-\text { cancel }_{s, t}
\end{aligned}
$$

where $S_{s, t}$ refers to labour supply that captures a pool of job seekers in sector $s$ in period $t$. The measure is calculated by adding the number of unemployed workers in the period t-1 $\left(U_{s, t-1}\right)$, the number of workers who are newly unemployed in the period $\mathrm{t}\left(\right.$ new $\left.U_{s, t}\right)$, the number of workers with tenure below 12 months (Short term $E_{s, t}$ ), and the number of workers who are inactive in the period $t$ but their last employment in period $t-1$ was in the sector $\left(I_{s, t}\right)$. The labour demand $D_{s, t}$ refers to a pool of posted vacancies in sector $s$ in period $t$. The measure is calculated by adding the number of posted vacancies in the period $t-1\left(V_{s, t-1}\right)$, the new vacancies posted in the period $t\left(n e w V_{s, t}\right)$, and subtracting the number of vacancies removed in the period $t$ (see technical Appendix 3 for more details and references). We then proceed with the augmented specification of the matching function to estimate labour market matching efficiency $\lambda_{s, t}^{\prime}$ :

$$
\log \left(H_{s, t}\right)=\log \left(\lambda_{s, t}^{\prime}\right)+\beta_{1} \log \left(S_{s, t}\right)+\beta_{2} \log \left(D_{s, t}\right)+\omega_{s, t}
$$

In the second stage, we evaluate the role of unemployment, labour market tightness and matching efficiency variables on $\overline{L S P}_{s t}$ and $\overline{L S P W}_{s t}$. The regression model in the second-stage takes the following form:

$$
\begin{aligned}
& \overline{L S P}_{s t}=\alpha_{1} U_{s t}+\alpha_{2} \theta_{s, t}+\alpha_{3} \theta_{s, t}^{\prime}+\alpha_{4} \lambda_{s, t}^{\prime}+\mu_{s}+\tau_{t}+\vartheta_{s t} \\
& \overline{L S P}_{s t}=\alpha_{1} U_{s t}+\alpha_{2} \theta_{s, t}+\alpha_{3} \theta_{s, t}^{\prime}+\alpha_{4} \lambda_{s, t}^{\prime}+\mu_{s}+\tau_{t}+\vartheta_{s t}
\end{aligned}
$$

The error term includes sector- and time-fixed effects to account for period-specific and sectorspecific changes. Table 1 includes a description of all variables in the first and second stages. We include descriptive statistics of variables in the first stage equation in Table A2 in the Appendix. 
Table 1 Description of first-stage and second-stage variables

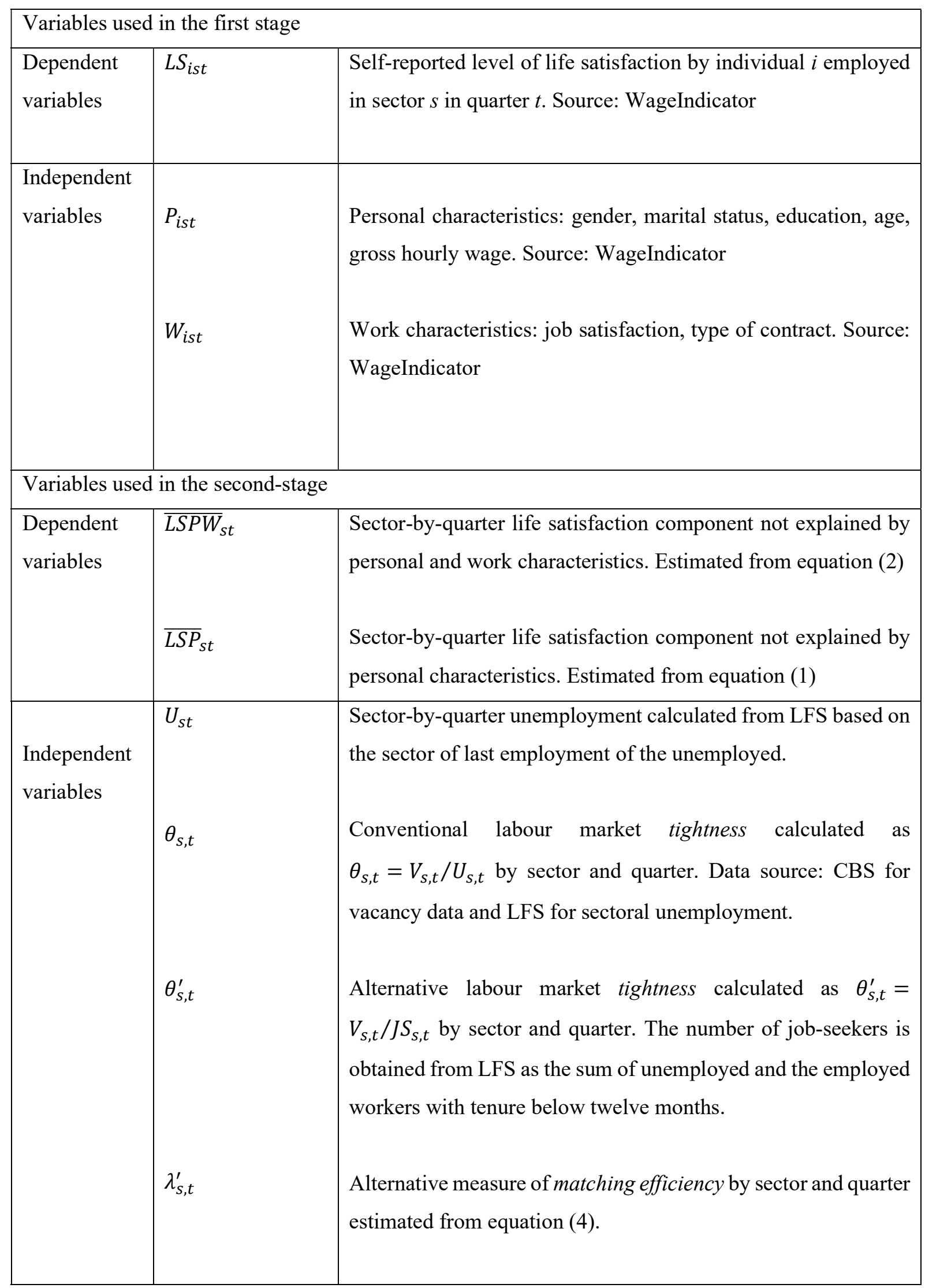

Source: WageIndicator, Labour Force Survey (LFS), Netherlands Statistics (CBS) 


\section{Data and results}

The empirical analysis in this paper combines several data sources. Individual data for life satisfaction variables are taken from the WageIndicator database; statistics on unemployment, newly employed, and job-seekers are sourced from the Labour Force Survey (LFS); and vacancy data is taken from Netherlands Statistics (CBS).

To construct the measure of LS, we use individual data obtained from a web-survey published on the websites of WageIndicator Foundation (Tijdens and Osse 2016). The use of web data to study labour market topics is gaining an increasing role (Kureková et al. 2015). The Dutch website is called "Loonwijzer" and is well-visited, reaching almost two million visitors per year. The website provides frequently-searched information about job-related content, such as labour law, minimum wages, cost of living, wages of celebrities, and a free 'salary check' with information about a counterpart's wages. In return for free information, web visitors are encouraged to complete a web-survey related to wages and working conditions. The survey also includes a question on satisfaction with life as a whole on a 10point scale where 1 is 'dissatisfied' and 10 is 'satisfied'. Because the questionnaires are collected continuously and in large numbers, it allows for a consistent measure of LS by quarter and sector. Our sample includes more than 100,000 valid observations (i.e. respondents who completed the online questionnaire) collected in the Netherlands between 2007 and 2014. The web-survey is a non-probability sample, but thanks to the large sample size, the data can be considered representative of the Dutch workforce in several dimensions. Of the total respondents in the sample, $43 \%$ are women, $35 \%$ have tertiary and $46 \%$ secondary education, the average age is 36 , about $43 \%$ are married, and $29 \%$ live in a rural area. ${ }^{3}$ The literature shows that some groups of Dutch workers, such as older and low educated workers, may be underrepresented in WageIndicator (Pedraza et al. 2007, 2010; Steinmetz et al. 2014; Tijdens et al. 2014). However, the literature also shows that the elasticities of salary regressions estimated using WageIndicator are not statistically different from those estimated using a random sample from official statistics like the Structures of Earnings Survey or EU Study of Income and Living Conditions survey (Pedraza et al. 2010; Fabo and Kahanec 2018). The WageIndicator database has also been proved to be consistent in studying the LS of workers in different domains (Guzi and Pedraza 2015) and job insecurity (Muñoz de Bustillo and Pedraza 2010). Table 2 reports the results of the estimations of equations (1) and (2).

\footnotetext{
${ }^{3}$ Based on the pooled LFS 2007-2014, the population of employed workers in the Netherlands has an average age of 40 years, $47 \%$ of women, $61 \%$ married, $32 \%$ tertiary educated, and $45 \%$ living outside of densely populated areas.
} 
Table 2 Individual life-satisfaction estimations of equations (1) and (2)

\begin{tabular}{|c|c|c|}
\hline Dependent variable & $\begin{array}{l}\qquad L S_{\text {ist }} \\
\text { Self-reported level of life } \\
\text { satisfaction by individual } i \\
\text { employed in sector } s \text { in } \\
\text { quarter } t \\
\quad(1)\end{array}$ & $\begin{array}{l}\qquad L S_{i s t} \\
\text { Self-reported level of life } \\
\text { satisfaction by individual } i \\
\text { employed in sector } s \text { in } \\
\text { quarter } t \\
\quad(2)\end{array}$ \\
\hline \multicolumn{3}{|l|}{$\begin{array}{l}\text { Personal and demographic } \\
\text { characteristics }\end{array}$} \\
\hline Gender & $\begin{array}{l}0.037 * * * \\
(0.010)\end{array}$ & $\begin{array}{l}0.076 * * * \\
(0.010)\end{array}$ \\
\hline Widowed & $\begin{array}{l}-0.744 * * * \\
(0.061)\end{array}$ & $\begin{array}{l}-0.691^{* * *} \\
(0.061)\end{array}$ \\
\hline Divorced & $\begin{array}{l}-0.489 * * * \\
(0.018)\end{array}$ & $\begin{array}{l}-0.451 * * * \\
(0.017)\end{array}$ \\
\hline Never married & $\begin{array}{l}-0.373 * * * \\
(0.012)\end{array}$ & $\begin{array}{l}-0.311 * * * \\
(0.012)\end{array}$ \\
\hline Education (ISCED 2) & $\begin{array}{l}0.209 * * * \\
(0.037)\end{array}$ & $\begin{array}{l}0.147 * * * \\
(0.038)\end{array}$ \\
\hline Education (ISCED 3-4) & $\begin{array}{l}0.288 * * * \\
(0.037)\end{array}$ & $\begin{array}{l}0.202 * * * \\
(0.037)\end{array}$ \\
\hline Education (ISCED 5) & $\begin{array}{l}0.447 * * * \\
(0.037)\end{array}$ & $\begin{array}{l}0.346 * * * \\
(0.037)\end{array}$ \\
\hline Education (ISCED 6) & $\begin{array}{l}0.475^{* * *} \\
(0.068)\end{array}$ & $\begin{array}{l}0.367 * * * \\
(0.067)\end{array}$ \\
\hline Age & $\begin{array}{l}-0.078^{* * *} \\
(0.003)\end{array}$ & $\begin{array}{l}-0.072 * * * \\
(0.003)\end{array}$ \\
\hline Age square $/ 100$ & $\begin{array}{l}0.085 * * * \\
(0.004)\end{array}$ & $\begin{array}{l}0.079 * * * \\
(0.004)\end{array}$ \\
\hline Rural residence & $\begin{array}{l}0.105 * * * \\
(0.010)\end{array}$ & $\begin{array}{l}0.074 * * * \\
(0.010)\end{array}$ \\
\hline Gross hourly wage (log) & $\begin{array}{l}0.169 * * * \\
(0.008)\end{array}$ & $\begin{array}{l}0.120 * * * \\
(0.008)\end{array}$ \\
\hline Work characteristics & & \\
\hline Satisfaction with job (1-5) & . & $\begin{array}{l}0.377 * * * \\
(0.004)\end{array}$ \\
\hline Permanent contract & . & $\begin{array}{l}0.157 * * * \\
(0.011)\end{array}$ \\
\hline Constant & $\begin{array}{l}8.237 * * * \\
(0.085)\end{array}$ & $\begin{array}{l}6.842 * * * \\
(0.085)\end{array}$ \\
\hline $\mathrm{N}$ & 112,122 & 99,152 \\
\hline $\mathrm{R}^{2}$ & 0.030 & 0.111 \\
\hline $\mathrm{L} 1$ & -207528.3 & -174128.7 \\
\hline
\end{tabular}

Source: WageIndicator data 2007-2014. Note: LS responses are measured from 1 to 10 , where 1 is "dissatisfied" and 10 is "satisfied". Both models include 14 sectoral and 7 yearly dummies. Reference groups: for marital status is Married; for education is Primary education (ISCED 1). Standard errors in parentheses. ${ }^{*} \mathrm{p}<0.1 ; * * \mathrm{p}<0.05 ; * * * \mathrm{p}<0.01$. 
We checked whether the OLS regression quantitatively produced the same substantive conclusions as an ordered probit regression. The estimates from the regression were also consistent with the results from the literature, and estimated coefficients of the micro-econometric equations had the expected sign: higher education, being married, having a better salary, a permanent contract, and being satisfied with one's job have a positive impact on reported LS. The large sample size and the continuous nature of the sample made it possible to organise residuals by quarters and 14 sectors (see Table A1 in the Appendix for sector classification). The sectoral approach is commonly used in the search and matching literature (Sahin et al. 2013; Broersma and van Ours 1999). Although one of the limitations of this approach is the assumption that job-seekers look for a job and explore search and matching circumstances within the same sector, there is some evidence of a job search across different sectors (Abraham 2015). ${ }^{4}$

In order to obtain the relevant measure of labour market tightness, $\theta^{\prime}=V / J S$, we need to account for the number employed job-seekers that is unknown. The literature shows that job search attitudes differ by job tenure spells (Gerritsen and Hoj 2013), with the longer workers have been employed, the lower their search intensity (Kahn 2012). As workers with longer tenures and permanent contracts are better protected and have higher severance rights, they are less likely to be fired or leave their jobs and therefore to become active job-seekers. These findings motivate the use of short-term employed workers as a proxy of employed job-seekers in the calculation of labour market tightness $\theta$ ' (Pedraza et al. 2018).

Matching efficiency relates to the ability of labour markets to match job-seekers to vacant jobs. We could estimate matching efficiency $\left(\lambda_{s, t}\right)$ from (3), using a panel data set constructed by combining quarterly data on the number of new hires, $\left(H_{s, t}\right)$, vacancies $\left(V_{s, t-1}\right)$, and unemployed $\left(U_{s, t-1}\right)$, distinguished at the sectoral level. The number of hires, taken from the LFS, encompasses workers employed in a reference week who started work within the previous three months. ${ }^{5}$ Sectoral unemployment is calculated from the LFS based on the sector of the last employment of the unemployed. The unemployed workers without employment history (e.g. young people) are distributed to sectors proportionally based on the employment size of the sector (Sahin et al. 2013; Broersma and van Ours 1999). The vacancy data from the CBS includes the stock of vacancies reported quarterly by employers. According to the literature, estimating matching efficiency using (3) may lead to bias estimates because of omitted variables (Barnichon and Figura 2015). By using the aforementioned more accurate measures of labour supply $\left(S_{s, t-1}\right)$ and labour demand $\left(D_{s, t-1}\right)$ in equation $(4)$, we improve the model fit and

\footnotetext{
${ }^{4}$ In general, there are two approaches to construct a country panel. The sectoral approach assumes that a worker previously employed in a sector will look for a job in that sector. The regional approach assumes that a worker previously employed in a region will look for a job in that region. Both approaches can be criticized due to workers' mobility between sectors and regions. We prefer the sectoral approach for three reasons. First, we have access to vacancy data distinguished by sectors but not by regions. Statistics Netherlands (CBS) suggested the use of sectoral vacancy data (Pedraza et al. 2019; Pedraza et al. 2018). Second, studies that estimate matching functions in the Netherlands follow the sectoral approach (Sahin et al. 2013; Broersma and van Ours 1999). Third, the sectoral approach facilitates the comparison with other studies estimating the matching function and the interpretation of results.

${ }^{5}$ In the LFS, employed individuals can be distinguished by tenure categories: 3-5 months, 6-12 months, 1-2 years, and more than 2 years. We use tenure less than 3 months to identify new hires.
} 
hence we obtain more precise estimates of the matching efficiency $\left(\lambda_{s, t}^{\prime}\right)$. The labour supply measure is augmented to include employed workers who search for a job. We use a similar assumption as for labour market tightness and include short-term employed workers, for less than twelve months, as part of labour supply in equation (4). The labour demand measure is calculated by summing the total stock of vacancies with the new vacancies posted and subtracting the removed vacancies in that quarter. In summary, we follow stylized facts from the literature to obtain robust estimates of matching efficiency and a labour market tightness measure that is relevant to employed workers. Table 3 displays the estimation results of the matching function specifications (3) and (4). Column 1 (2) presents the estimation of the standard matching function (augmented specification of the matching function). Both estimations show a good fit in terms of the R-squared measure. According to recent literature, the traditional specification in Column 3 leads to biased estimates. The augmented specification fits the data better and adjusts better to the business cycle and displays constant returns to scale, which is a cornerstone assumption in unemployment equilibrium models (Pedraza et al. 2018; Pissarides 2000) ${ }^{6}$. The elasticity of the matching function with respect to labour supply $(0.74)$ ranks among the highest estimates found in the literature (Petrongolo and Pissarides 2001). The elasticity with respect to labour demand (0.27) is smaller than estimates found in the literature but similar to some studies (Jolivet 2009). The sum $0.74+0.27$ implies the constant returns to scale. We proceed with the augmented specification to estimate labour market matching efficiency $\lambda_{s, t}^{\prime}$ for the second-stage.

Results from the second-stage are presented in Table 4. Dependent variables are the regressioncorrected LS levels from the first stage OLS regressions (Table 2). Estimates in the second column are based on a LS measure adjusted for individual characteristics (obtained from equation 1) and estimates in the third column employ a LS measure adjusted for individual and working characteristics (obtained from equation 2), referred to as $\overline{L S P}_{s t}$ and $\overline{L S P W}_{s t}$, respectively. The five-quarter moving averages of explanatory variables are used to smooth noise in the data. Note that Di Tella et al. (2001) apply a threeyear moving average on annual data.

\footnotetext{
${ }^{6}$ Equation (3) suffers from omitted variables bias because it does not account for heterogeneities among job seekers and vacancies. Elasticities of hires with respect to unemployed are procyclical while elasticities with respect to short term employed are countercyclical. Similarly, elasticities among different types of vacancies differ and change with the business cycle. This is the reason why more accurate measures display more stable results through time. Constant returns to scale imply that if the number of job-seekers and vacancies increases, the number of hires increases proportionally, which is generally accepted in theoretical models.
} 
Table 3 Matching function estimations of equations (3) and (4).

\begin{tabular}{lll}
\hline & $\ln H_{s, t}$ & $\ln H_{s, t}$ \\
& $(3)$ & $(4)$ \\
\hline $\ln V_{s, t-1}$ & $0.614^{* * *}$ & \\
$\ln U_{s, t-1}$ & $(0.038)$ & \\
& $0.200^{* * *}$ & \\
\hline $\ln D_{s, t}$ & $(0.030)$ & $0.273^{* * *}$ \\
$\ln S_{s, t}$ & & $(0.037)$ \\
& & $0.736^{* * *}$ \\
\hline Constant & & $(0.039)$ \\
\hline Observations & $3.294^{* * *}$ & $-0.562^{* * *}$ \\
\hline R-squared & $(0.320)$ & $(0.183)$ \\
\hline ll & 714 & 733 \\
\hline Sorce Ls and & 0.862 & 0.904 \\
\hline
\end{tabular}

Source: LFS and CBS. Note: Dependent variable is the number of new hires approximated by workers who started work within the previous three months. $S_{s, t}$ and $D_{s, t}$ calculated as explained in the Appendix 3 (Pedraza et al. 2018).

Standard errors in parentheses. $* \mathrm{p}<0.1 ; * * \mathrm{p}<0.05 ; * * * \mathrm{p}<0.01$.

Unemployment at sectoral levels displays a remarkably robust negative relationship to LS in both specifications. This means that the LS of employed workers is sensitive to the unemployment levels in their sector of activity, and this result is confirmed also for workers with a stable and satisfying job (third column where the LS measure is corrected for the type of contract and one's satisfaction with a job). This finding is consistent with the literature that documents the negative effect of national unemployment levels (Di Tella et al. 2001, 2003) and proves the consistency of the sectoral approach. The estimates in Table 4 further demonstrate that temporary fluctuations of LS are sensitive to labour market circumstances driven by market power and matching efficiency. The employed are concerned about labour market circumstances, among other reasons, because many of them actively look for a job. This is consistent with the stylized fact in the search and matching literature (Veracierto 2011; Sedláček 2016; Hall and Schulhofer-Wohl 2015; Van Ours 2015). Estimates show that the conventional measure of labour market tightness, i.e. the number of vacancies per unemployed worker $(\theta=\mathrm{V} / \mathrm{U})$, is not significant, but the alternative labour market tightness measure that accounts for employed job-seekers $\left(\theta^{\prime}=\mathrm{V} / \mathrm{JS}\right)$ is significant. ${ }^{7}$ Employed individuals are concerned about job competition with employed

\footnotetext{
${ }^{7}$ We checked that this finding remains valid if we include two indicators of labour market tightness separately. To keep the presentation of results concise, we prefer to include both indicators simultaneously. Results are available from the authors upon request.
} 
rather than with unemployed individuals; labour market tightness is better described by $\theta$ ' than $\theta$. This outcome is consistent with the observation that employers prefer to hire employed workers rather than unemployed individuals (Diamond and Sahin 2015; Van Belle et al. 2018), and thus employed jobseekers tend to compete with other employed job-seekers.

The estimate on $\theta^{\prime}$ is significant in both specifications with different LS measures, indicating that labour market tightness is important to workers' LS regardless of their working conditions. ${ }^{8}$ A higher ratio of vacancies per job-seeker may give workers more bargaining and market power, which may increase the LS of all workers and also those satisfied with their job.

Table 4 Life satisfaction estimations of equations (5) and (6)

\begin{tabular}{|c|c|c|}
\hline Dependent variables & 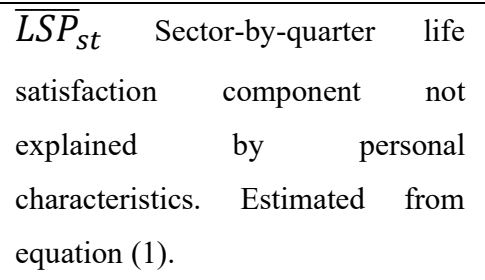 & $\begin{array}{l}\overline{L S P W}_{\text {st }} \text { Sector-by-quarter } \\
\text { life satisfaction component not } \\
\text { explained by personal and } \\
\text { work characteristics. Estimated } \\
\text { from equation (2) }\end{array}$ \\
\hline$U_{s, t}$ & $\begin{array}{l}-6.970 \text { *** } \\
(1.420)\end{array}$ & $\begin{array}{l}-6.368 * * * \\
(1.328)\end{array}$ \\
\hline$\theta_{s, t}=V_{s, t} / U_{s, t}$ & $\begin{array}{l}-0.057 \\
(0.042)\end{array}$ & $\begin{array}{l}-0.051 \\
(0.039)\end{array}$ \\
\hline$\theta_{s, t}^{\prime}=V_{s, t} / J S_{s, t}$ & $\begin{array}{l}0.067 * * * \\
(0.021)\end{array}$ & $\begin{array}{l}0.047 * * \\
(0.020)\end{array}$ \\
\hline$\lambda_{s, t}^{\prime}$ & $\begin{array}{l}0.124 * * \\
(0.060)\end{array}$ & $\begin{array}{l}0.078 \\
(0.056)\end{array}$ \\
\hline Constant & $\begin{array}{l}0.504 * * * \\
(0.114)\end{array}$ & $\begin{array}{l}0.478 * * * \\
(0.107)\end{array}$ \\
\hline Observations & 373 & 373 \\
\hline Overall $\mathrm{R}^{2}$ & 0.24 & 0.22 \\
\hline
\end{tabular}

Note: Models include fixed effects for year, quarter, and sector. A five-quarter moving average centred at $\mathrm{t}-3$ is applied to smooth the noise in the data. Standard errors in parentheses. ${ }^{*} \mathrm{p}<0.1 ; * * \mathrm{p}<0.05 ;{ }^{* * *} \mathrm{p}<0.01$.

The estimate on matching efficiency is significant and positive only in the model with the LS measure not adjusted for working conditions. It follows that efficiently-operating labour markets improve the LS of workers who are less satisfied with their job and in temporary employment. The potential explanation

\footnotetext{
${ }^{8}$ Estimating the model separately by gender, we confirm that conventional labour market tightness is not significant in any model. The unemployment is significant for men and alternative tightness and matching efficiency is significant for women at the $1 \%$ level.
} 
is that this group of workers is more likely to search for a job and the higher matching efficiency eases the job-search process.

\section{Conclusions}

In this paper, we show that labour market circumstances measured by sectoral unemployment, matching efficiency, and market tightness (Pissarides 2000; Petrongolo and Pissarides 2001) are related to the LS of employed workers. Evidence from psychology shows that LS levels are stable in the long-term, and temporary variations occur due to external circumstances (Lucas and Donnellan 2007; Lucas 2007). The results of our study confirm our main hypothesis: A worker's LS is sensitive to labour market search and matching circumstances. The novelty of our approach is of interest to two streams of literature: life satisfaction and search and matching. As far as we know, no evidence of this relationship has been documented before. We also corroborate, at the sectoral level, results from the literature (e.g. Di Tella et al. 2003) that a high unemployment rate has deleterious effects on workers' LS.

The way we calculate LS and labour market measures is very important to understanding our findings. Regarding LS measures, we assume that the concerns and circumstances of workers satisfied with their job and with a permanent contract are different from the concerns of dissatisfied workers and in temporary employment (Leuchinger et al. 2010; Bjørnskov 2014; Böckerman et al. 2011; Theodossiou and Vasileiou 2007; Origo and Pagani 2009; Muñoz de Bustillo and Pedraza 2010). Therefore, we calculate two LS measures, the first accounting only for personal characteristics and the second also accounting for working conditions.

Regarding the calculation of labour market measures, we assume that employed and unemployed job-seekers face different search and matching circumstances and probably compete for different jobs. We base this assumption on empirical evidence that shows, for example, that employers generally prefer employed to unemployed job applicants (Diamond 2011; Diamond and Sahin 2015; Van Belle et al. 2018). The calculated labour market tightness and matching efficiency build upon recent findings in the search and matching literature (Veracierto 2011; Hall and Schulhofer-Wohl 2015; Van Ours 2015; Abraham 2015; Barnichon and Figura 2015). Accordingly, we first broaden the definition of job-seekers to construct an alternative measure of labour market tightness. Second, in order to incorporate labour force heterogeneity and the role of employed job-seekers, we expand the standard matching function by using more accurate definitions of labour supply and demand (Jolivet 2009; Sedláček 2016; Pedraza et al. 2018).

Our findings imply that when there are more vacant jobs per job-seeker and higher matching efficiency, workers' LS is also higher. A higher number of vacancies per job-seeker increases the bargaining power of every worker, regardless of whether they are satisfied with their job and have a permanent contract. Therefore, the positive relationship holds for both LS measures. Labour market 
matching efficiency is related only with the LS measure that does not account for working conditions. A possible interpretation is that workers who are less satisfied with their job and in temporary employment are more likely to look for another job (Gerritsen and Høj 2013). More research is required before reaching additional conclusions at the individual level.

Our findings have relevant policy implications. Policy measures that increase the number of vacancies, such as activating demand for labour, have the potential to improve the LS of the entire employed population. If the number of vacancies per job seeker increased, employed job-seekers would have more chances to find their match, and employed individuals not looking for a job would be in a better position to negotiate their current wages and conditions. Measures to improve the efficiency of job-matching, ranging from education and training aimed at better matching labour demand and workers' skills to reducing information frictions, e.g. by supporting match-making technologies, have probably a stronger effect on the well-being of job seekers.

Despite the strengths and novelty of the current study, it has limitations that should be noted and taken into consideration in future research. First, although the sectoral approach is commonly used in the search and matching literature (Sahin et al. 2013; Broersma and van Ours 1999), it implies assuming that job-seekers look for a job and explore search and matching circumstances within the sector in which they are currently working. There is evidence that a job-search is very often conducted across different sectors (Abraham 2015). Second, the paper focuses on employed workers and the conclusion cannot be extrapolated to the whole labour force. Finally, we have explored a specific country during a specific period. Our future research efforts will focus on testing the consistency of the above findings when exploring other countries and other aggregation levels, beyond the sectoral approach.

\section{Acknowledgement}

The scientific output expressed does not imply a policy position of the European Commission. Neither the European Commission nor any person acting on behalf of the Commission is responsible for use that may be made of this publication. The authors would like to acknowledge the Marie Curie Initial Training Networks (FP7-PEOPLE-2013-ITN) project 'EDUWORKS: Crossing borders in the comprehensive investigation of labour market matching processes: An EU-wide, trans-disciplinary, multilevel and science-practice-bridging training network'. The authors are grateful to WageIndicator Foundation for data from its web-survey. Martin Guzi acknowledges support from the Grant Agency of Masaryk University (MUNI/A/1123/2017 and MUNI/A/1118/2018). The authors would also like to acknowledge www.webdatanet.eu (Cost action IS1004) and to thank participants at the AIAS lunch seminar for their comments and suggestions. 


\section{References}

Abraham, K.G. (2015). Is skill mismatch impeding U.S. economic recovery? Industrial and Labor Relations Review, 68(2), pp.291-313.

Akay, A., Constant, A., Giulietti, C., \& Guzi, M. (2017). Ethnic diversity and well-being. Journal of Population Economics, 30(1), pp.265-306.

Barnichon, R. \& Figura, A. (2015). Labor market heterogeneity and the aggregate matching function. American Economic Journal: Macroeconomics, 7(4), pp.222-249.

Biswas-Diener, R., Kashdan, T.B., \& King, L.A. (2009) Two traditions of happiness research, not two distinct types of happiness, The Journal of Positive Psychology, 4:3, 208-211.

Bjørnskov, C. (2014). Do Economic Reforms Alleviate Subjective Well-Being Losses of Economic Crises? Journal of Happiness Studies, 15(1), pp.163-182.

Blanchflower, D.G., Bell, D. N., Montagnoli, A., \& Moro, M. (2014). The Happiness Trade-Off between Unemployment and Inflation. Journal of Money, Credit and Banking, 46(S2), pp.117-141.

Böckerman, P., Ilmakunnas, P., \& Johansson, E. (2011). Job security and employee well-being: Evidence from matched survey and register data. Labour Economics, 18(4), pp.547-554.

Broersma, L. \& Van Ours, J.C. (1999). Job Searchers, Job Matches and the Elasticity of Matching. Labour Economics, 6(1), pp.77-93.

Diamond, P. (2011). Unemployment, vacancies, wages. American Economic Review, 101(4), pp.10451072.

Diamond P.A. \& Sahin A. (2015). Shifts in the Beveridge Curve. To appear in Research in Economics, vol.69 issue 1, pp.18-25.

Dickerson, A. \& Green, F. (2012). Fears and realisations of employment insecurity. Labour Economics, 19(2), pp.198-210.

Dluhosch, B. \& Horgos, D. (2013). Trading Up the Happiness Ladder. Social Indicators Research, 113(3), pp.973-990.

Fabo, B. \& Kahanec, M. (2018). Can a voluntary web survey be useful beyond explorative research? International Journal of Social Research Methodology, 21(5), pp.591-601.

Gerritsen, M. \& Høj, J. (2013). The Dutch Labour Market, OECD Publishing.

Guzi, M. \& Pedraza, P. de (2015). A web survey analysis of subjective well-being. International Journal of Manpower, 36(1), pp.48-67.

Hall, R. \& Schulhofer-Wohl, S. (2015). Measuring job-finding rates and matching efficiency with heterogeneous job-seekers. NBER Working paper series, Working paper 20939.

Jolivet, G. (2009). A longitudinal analyses of search frictions and matching in the U.S. labor market. Labour Economics 16 (2009) 121-134. 
Kahn, L.M. (2012). Temporary jobs and job search effort in Europe. Labour Economics, 19(1), pp.113128.

Kahneman, D. \& Sugden, R. (2005). Experienced utility as a standard of policy evaluation. Environmental and Resource Economics, 32(1), pp.161-181.

Kureková, L.M., Beblavý, M., \& Thum-Thysen, A. (2015). Using online vacancies and web surveys to analyse the labour market: a methodological inquiry. IZA Journal of Labor Economics, 4(1), p.18.

Lucas, R.E. (2007). Personality and the Pursuit of Happiness. Social and Personality Psychology Compass 1/1 (2007): 168-182.

Lucas, R.E. \& Donnellan, M.B. (2007). How stable is happiness? Using the STARTS model to estimate the stability of life satisfaction. Journal of Research in Personality 41 (2007) 1091-1098.

Lucas, R.E., Clark, A.E., Georgellis, Y., \& Diener, E. (2003). Reexamining adaptation and the set point model of happiness: reactions to changes in marital status. Journal of Personality and Social Psychology, 84, 527-539.

Luechinger, S., Meier, S., \& Stutzer, A. (2010). Why does unemployment hurt the employed?: Evidence from the life satisfaction gap between the public and the private sector. Journal of Human Resources, 45(4), pp.998-1045.

McKee-Ryan, F.M., Kinicki, A.J., Song, Z., \& Wanber, C.R. (2005). Psychological and Physical WellBeing During Unemployment: A Meta-Analytic Study. Journal of Applied Psychology, Vol. 90, No. 1, 53-76.

Muñoz de Bustillo, R. \& Pedraza, P. de (2010). Determinants of job insecurity in five European countries. European Journal of Industrial Relations, 16(1), pp.5-20.

Origo, F. \& Pagani, L. (2009). Flexicurity and job satisfaction in Europe: The importance of perceived and actual job stability for well-being at work. Labour Economics, 16(5), pp.547-555.

Paul, K.I., \& Moser, K. (2009). Unemployment impairs mental health. Journal of Vocational Behaviour, 74 (2009), pp. 264-282

Pedraza, P. de, Tijdens, K.G., \& Muñoz de Bustillo, R. (2007). Sample bias, weights and efficiency of weights in a continuous web voluntary survey, Amsterdam Institute for Advanced labour Studies, University of Amsterdam.

Pedraza, P. de, Tijdens, K.G., \& Muñoz de Bustillo, R. (2010). A Spanish Continuous Volunteer Web Survey: Sample Bias, Weighting and Efficiency. Revista Espanola De Investigaciones Sociologicas, (131), pp.109-130.

Pedraza, P. de, Visintin, S., \& Tijdens, K.G. (2018). The Dutch labour market matching function before and after the crisis. International Journal of Manpower, vol 39, issue 8, pp. 1010-1031.

Pedraza, P. de, Visintin, S., Tijdens, K.G. \& Kishmihok, G. (2019). Survey vs Scraped Data: Comparing Time Series Properties of Web and Survey Vacancy Data. IZA Journal of Labour Economics, 2019, $8(1)$.

Petrongolo, B. \& Pissarides, C.A. (2001). Looking into the Black Box: A Survey of the Matching Function. Journal of Economic Literature, 39(2), pp.390-431. 
Pissarides, C.A. (2000). Equilibrium unemployment Theory, MIT second ed., Cambridge, MA: MIT Press.

Pizzinelli, C. \& Speigner, B. (2017). Matching efficiency and labour market heterogeneity in the United Kingdom. Bank of England Staff Working Paper N. 667. https://www.bankofengland.co.uk//media/boe/files/working-paper/2017/matching-efficiency-and-labour-market-heterogeneity-inthe-uk

Sahin, A., Song, J., Topa, G., \& Violante, G.L. (2013). Mismatch Unemployment. Staff R No. 566, Federal Reserve Bank of New York. June.

Sedláček, P. (2016). The aggregate matching function and job search from employment and out of the labor force. Review of Economic Dynamics, 21, pp.16-28.

Silla, I., De Cuyper, N., Gracia, F. J., Peiró, J. M., \& De Witte, H. (2009). Job insecurity and well-being: Moderation by employability. Journal of Happiness Studies, 10(6), pp.739-751.

Steinmetz, S., Bianchi, A., Tijdens, K., \& Biffignandi, S. (2014). Improving web survey quality: Potentials and constraints of propensity score adjustments. In Online Panel Research: A Data Quality Perspective. pp. 273-298.

Synard, J. \& Gazzola, N. (2017). Happiness, eudaimonia, and other holy grails: What can job loss teach us about "One-size-fits-all" theories of well-being? The Journal of Positive Psychology.

Tella, R. Di, Macculloch, R.J., \& Oswald, A.J. (2001). American Economic Association Preferences over Inflation and Unemployment: Evidence from Surveys of Happiness. Source: The American Economic Review, 91(1), pp.335-341.

Tella, R. Di, MacCulloch, R., \& Oswald, A.J. (2003). The Macroeconomics of Happiness. Review of Economics and Statistics, 85(4), pp.809-827.

Theodossiou, I. \& Vasileiou, E. (2007). Making the risk of job loss a way of life: Does it affect job satisfaction? Research in Economics, 61(2), pp.71-83.

Tijdens, K.G., Van Klaveren, M., Bispinck, R., Dribbusch, H., \& Öz, F. (2014). Wage and workforce adjustments in the economic crisis in Germany and the Netherlands. European Journal of Industrial Relations, 20, pp.165-183.

Tijdens, K.G. \& Osse, P. (2016). WageIndicator continuous web-survey on work and wages. Dataset. Data available at: https://datasets.iza.org/dataset/59/wageindicator-survey

Van Belle, E., Di Stasio, V., Caers, R., De Couck, M., \& Baert, S., (2018). Why Are Employers Put Off by Long Spells of Unemployment? European Sociological Review, 34(6), pp. 694-710.

Van Ours, J.C. (2015). The Great Recession was not so great. Labour Economics 34, 1-12.

Veracierto, M. (2011). Worker Flows and Matching Efficiency. Federal Reserve Bank of Chicago Economic Perspectives, pp.147-169. 


\section{Appendix 1}

Table A1 Classification of 14 sectors based on NACE Rev2.

A Agriculture, forestry and fishing

B Mining and quarrying

C Manufacturing

D\&E Electricity, gas, steam and air conditioning supply; Water supply; sewerage, waste management and remediation activities

F Construction

G Wholesale and retail trade; repair of motor vehicles and motorcycles

H\&J Transportation and storage; Information and communication

I Accommodation and food service activities

K Financial and insurance activities

L\&M\&N Real estate activities; Professional, scientific and technical activities; Administrative and support service activities

O Public administration and defence; compulsory social security

P Education

Q Human health and social work activities

R\&S Arts, entertainment and recreation; Other service activities 
Table A2 Descriptive statistics

\begin{tabular}{lrrrr}
\hline & Mean & S.D. & Min & \multicolumn{2}{r}{ Max } \\
\hline Life-satisfaction & 7.26 & 1.56 & 1 & 10 \\
Female & 0.44 & 0.50 & 0 & 1 \\
Married & 0.43 & 0.49 & 0 & 1 \\
Widowed & 0.01 & 0.08 & 0 & 1 \\
Divorced & 0.09 & 0.28 & 0 & 1 \\
Never married & 0.48 & 0.50 & 0 & 1 \\
Education (ISCED 1) & 0.02 & 0.13 & 0 & 1 \\
Education (ISCED 2) & 0.19 & 0.39 & 0 & 1 \\
Education (ISCED 3-4) & 0.44 & 0.50 & 0 & 1 \\
Education (ISCED 5) & 0.35 & 0.48 & 0 & 1 \\
Education (ISCED 6) & 0.01 & 0.08 & 0 & 1 \\
Age & 36.3 & 10.7 & 18 & 60 \\
Rural residence & 0.30 & 0.46 & 0 & 1 \\
Gross hourly wage & 16.8 & 12.5 & 1.7 & 173 \\
Satisfaction with job & 3.60 & 1.14 & 1 & 5 \\
Permanent contract & 0.77 & 0.42 & 0 & 1 \\
\hline Source: Wagelndicator & & & & \\
\hline
\end{tabular}

Source: WageIndicator 


\section{Appendix 2 Inclusion of unemployed without a previous sector}

We used European LFS data for unemployment. We assigned a sector to unemployed individuals according to their previous job's sector. Taking only these unemployed people with a previous sector into account would have omitted from the analyses (Broesma and van Ours 1999) unemployed people without previous jobs. These are mainly young new entrants and women attempting to re-join the labour force. In order to assign them to a sector, we assume that each sector of activity is a labour market segment, that unemployed workers search in a labour market segment in which they are more likely to find a job, and that the aggregated probabilities of unemployed workers without previous sectors of finding a job in each specific sector equals the employment of that sector as a proportion of total employment. This is the method used and tested by Pedraza et al. (2018). They use this method to generate a category of unemployed people that they assume to be a proxy for potential new entrants or re-entrants in each sector (Unewentrants).

$$
U_{\text {newentrantsi }, t}=U_{u, t} \frac{E_{i, t}}{\sum_{i=1}^{n} E_{i, t}}
$$

Where $U_{u, t}$ is the total number of unemployed people in quarter $t$ whose sector is unknown. $E_{i, t}$ is the number of employed people in sector $\mathrm{i}$ in quarter $\mathrm{t}$.

\section{Appendix $3 S$ and $D$ measures in Equation 4}

The conventional matching function assumes that only unemployed workers search for jobs. Recent studies show that changes in matching efficiency can be explained by heterogeneities in both sides of the labour market. Ignoring different types of job-seekers and vacancies in the matching function produces an omitted variable bias in the estimated matching efficiency (Veracierto 2011; Barnichon and Figura 2015; Sedlacek 2016; Pizzinelli and Speigner 2017; Sedladek 2016). Pedraza et al. (2018) show how their augmented specification improves the model's fit and displays constant returns to scale across the business cycle. They estimate the following:

$$
\begin{aligned}
& \log \left(H_{s, t}\right)=\log \left(\lambda_{s, t}^{\prime}\right)+\beta_{1} \log \left(S_{s, t}\right)+\beta_{2} \log \left(D_{s, t}\right)+\omega_{s, t} \\
& S_{s, t}=U_{s, t-1}+\text { new } U_{s, t}+\text { newentrants } U_{s, t}+\text { Short term } E_{s, t}+I_{s, t} \\
& D_{s, t}=V_{s, t-1}+\text { new } V_{s, t}-\text { cancel }_{s, t}
\end{aligned}
$$

where $S_{s, t}$ refers to labour supply and captures a pool of job-seekers that can generate hirings in sector $s$ in period $t$. It is calculated by adding the following to the traditional measure: the number of 
unemployed workers at the end of the period t-1 $\left(U_{s, t-1}\right)$, the number of workers that enter unemployment during the first month of period $\mathrm{t}\left(\right.$ new $\left.U_{s, t}\right)$, plus unemployed workers without a sector that are considered to be new entrants in the labour force (newentrants $U_{s, t}$ ), plus the number of shortterm employed workers that have found their current job during the last year (Short term $E_{S, t}$ ), plus a proportion of inactive workers that have worked before in that sector and that may generate hires as they can re-enter the labour force $\left(I_{s, t}\right)$. $D_{s, t}$ refers to labour demand, a pool of posted vacancies that can generate hirings in sector $s$ in period $t$. The measure is calculated by adding the following to the traditional measure: the number of posted vacancies in sector $\mathrm{s}$ at the end of period $t-1\left(V_{s, t-1}\right)$, the new vacancies posted during period $t$ which is the flow of newly-posted vacancies $\left(n e w V_{s, t}\right)$, minus the number of vacancies that were cancelled during period $t$. By using the aforementioned more accurate measures of labour supply $\left(S_{s, t}\right)$ and labour demand $\left(D_{s, t}\right)$ in equation (4), we are able to obtain more precise estimates of the matching efficiency $\left(\lambda_{s, t}^{\prime}\right)$. We follow stylized facts from the literature to obtain robust estimates of matching efficiency and a labour market tightness measure that is relevant to employed workers. This appendix is not intended to be a complete review to motivate the specification of equation 4, but rather a short description of how it has been calculated. Our final goal is to avoid omitted variable bias in the estimations of matching efficiency (e.g. Barnichon and Figura 2015; Sedlacek 2016; Pizzinelli and Speigner 2017; Pedraza et al . 2018). The results from estimating equations (3) and (4) are presented in Table 3. Column 1 (2) presents the estimation of the standard matching function (augmented specification of the matching function). Both estimations show a good fit in terms of the R-squared measure. The augmented specification fits the data better and adjusts well to the business cycle (Pedraza et al. 2018).

We therefore proceed with the augmented specification to estimate labour market matching efficiency $\lambda_{s, t}^{\prime}$ for the second-stage (Equation 4). 


\section{MUNI Econ Working Paper Series (since 2018)}

2020-02 de Pedraza, P., Guzi, M., Tijdens, K. (2020). Life Satisfaction of Employees, Labour Market Tightness and Matching Efficiency. MUNI ECON Working Paper n. 2020-02. Brno: Masaryk University. https://doi.org/10.5817/WP_MUNI_ECON_2020-02

2020-01 Fišar, M., Reggiani, T., Sabatini, F., Špalek, J. 2020. a. MUNI ECON Working Paper n. 2020-01. Brno: Masaryk University. https://doi.org/10.5817/WP_MUNI_ECON_2020-01

2019-08 Fišar, M., Krčál, O., Špalek, J., Staněk, R., Tremewan, J. 2019. A Competitive Audit Selection Mechanism with Incomplete Information. MUNI ECON Working Paper n. 2019-08. Brno: Masaryk University. https://doi.org/10.5817/WP_MUNI_ECON_2019-08

2019-07 Guzi, M., Huber, P., Mikula, M. 2019. Old sins cast long shadows: The Long-term impact of the resettlement of the Sudetenland on residential migration. MUNI ECON Working Paper n. 2019-07. Brno: Masaryk University. https://doi.org/10.5817/WP_MUNI_ECON_2019-07

2019-06 Mikula, M., Montag, J. 2019. Does homeownership hinder labor market activity? Evidence from housing privatization and restitution in Brno. MUNI ECON Working Paper n. 2019-06. Brno: Masaryk University. https://doi.org/10.5817/WP_MUNI_ECON_2019-06

2019-05 Krčál, O., Staněk, R., Slanicay, M. 2019. Made for the job or by the job? A lab-in-the-field experiment with firefighters. MUNI ECON Working Paper n. 2019-05. Brno: Masaryk University. https://doi.org/10.5817/WP_MUNI_ECON_2019-05

2019-04 Bruni, L., Pelligra, V., Reggiani, T., Rizzolli, M. 2019. The Pied Piper: Prizes, Incentives, and Motivation Crowding-in. MUNI ECON Working Paper n. 2019-04. Brno: Masaryk University. https://doi.org/10.5817/WP_MUNI_ECON_2019-04

2019-03 Krčál, O., Staněk, R., Karlínová, B., Peer, S. 2019. Real consequences matters: why hypothetical biases in the valuation of time persist even in controlled lab experiments. MUNI ECON Working Paper n. 2019-03. Brno: Masaryk University. https://doi.org/10.5817/WP_MUNI_ECON_2019-03

2019-02 Corazzini, L., Cotton, C., Reggiani, T., 2019. Delegation And Coordination With Multiple Threshold Public Goods: Experimental Evidence. MUNI ECON Working Paper n. 2019-02. Brno: Masaryk University. https://doi.org/10.5817/WP_MUNI_ECON_2019-02

2019-01 Fišar, M., Krčál, O., Staněk, R., Špalek, J. 2019. The Effects of Staff-rotation in Public Administration on the Decision to Bribe or be Bribed. MUNI ECON Working Paper n. 2019-01. Brno: Masaryk University. https://doi.org/10.5817/WP_MUNI_ECON_2019-01

2018-02 Guzi, M., Kahanec, M. 2018. Income Inequality and the Size of Government: A Causal Analysis. MUNI ECON Working Paper n. 2018-02. Brno: Masaryk University. https://doi.org/10.5817/WP_MUNI_ECON_2018-02

2018-01 Geraci, A., Nardotto, M., Reggiani, T., Sabatini, F. 2018. Broadband Internet and Social Capital. MUNI ECON Working Paper n. 2018-01. Brno: Masaryk University. https://doi.org/10.5817/WP_MUNI_ECON_2018-01 
MUNI ECON Working Paper Series is indexed in RePEc:

https://ideas.repec.org/s/mub/wpaper.html 